\title{
The Effect of Bean Juice for Reduction Blood Glucose Levels in Psychological Stress
}

\author{
Dianti Ias Oktaviasari ${ }^{1,{ }^{*}}$, Reny Nugraheni ${ }^{1}$ \\ ${ }^{1}$ Faculty of Health Science, Institut Ilmu Kesehatan Bhakti Wiyata, Kediri, Indonesia \\ "Corresponding author.Email: dianti.oktaviasari@iik.ac.id
}

\begin{abstract}
The prevalence of psychological stress or known as mental emotional disorders in Indonesian population is 6\% or around 14 million people (Riskesdas, 2013). Psychological stress can occur people who staying up late with upside down sleep patterns. Psychological stress will affect the HPA Axis system in the body and increase cortisol hormone secretion, so it can increase metabolic processes and affect in increasing blood glucose levels. This psychological stress, can trigger oxidative stress which will increase the risk of degenerative diseases. Beans (Phaseolus vulgaris linn) have antioxidant activity that can provide protection against lipid peroxidation and enhance cellular antioxidant defenses so it can suppress oxidative stress process. The aim of this study was to examine the effectiveness of bean juice in reducing blood glucose levels in male white rats (strain wistar) exposed by psychological stress. This study was Randomized Post Test Only Group Design. There were five groups in this study, control and stress control groups, and 3 treatment groups. Psychological stress exposure was given to change sleep patterns in rats. These treatment groups were given bean juice dose 4,5 g/ml. Blood sample from each treatment group was taken after 1 hour, 6 hours, and 24 hours to measure blood glucose levels. The results showed that blood glucose levels can be reduced by providing bean juice in the first hour after psychological stress exposure. Flavonoid antioxidant content in beans, reduces the amount of free radicals by scavenging mechanisms on free radicals and increases endogenous antioxidant levels and insulin levels, so that blood glucose levels can be reduced. A single dose of bean juice in this study, can reduce blood glucose levels after one hour of giving bean juice and its antioxidant activity persisted until 24th hour. It showed that bean juice can work as an antioxidant by reducing blood glucose levels.
\end{abstract}

Keywords: oxidative stress, psychological stress, bean juice, blood glucose levels

\section{INTRODUCTION}

Psychological stress often suffers people with body disorders, such as person with an upside down sleep pattern [1]. High pressure and burden of living about social, economic and environmental conditions can also increase the risk of psychological stress [2]. Based on the data from Riskesdas (2013), prevalence of psychological stress or known as mental emotional disorders in Indonesian population is $6 \%$ or around 14 million people. This condition showed that mental health disorders are serious problem in Indonesia [3].

Acute stress conditions, whether caused by physical stress or psychological stress will affect the Axis Adrenal Hipothalamus (HPA) system in the body. Stimulus in hypothalamus, can increase adrenaline hormone and cortisol hormone secretion [4]. Enhancement of cortisol hormone secretion that is released as a response to psychological stress, causes increased metabolism, especially in gluconeogenesis and glycogenolysis process, and both of them have an impact in increasing blood glucose levels [5]. Glucose has molecules that are easily oxidized to produce reactive and radical molecules in blood. Increased blood glucose levels correlate with an increase in oxidative stress markers, named Malondialdehyde (MDA) levels in blood.

An imbalance between the formation of free radicals and antioxidant activity in the body causes oxidative stress [6]. Oxidative stress has consequences for body such as degenerative diseases [7], including Diabetes Mellitus (DM) [8], atherosclerosis, hypertension, ischemia, Alzheimer, Parkinson, cancer and inflammation which are caused by free radicals [9].

How to deal with psychological stress that has been done a lot is to provide post-stress rehabilitation to restore body rhythm, namely adequate rest and sleep. However, preventive treatment is needed as an early psychological stress management, so it can reduce the impact of psychological stress in the body. Body needs antioxidants that can protect body from free radicals attacks and radical compounds. Antioxidants in certain levels can inhibit damage caused by oxidation process [9]. Naturally, body does not have excess antioxidant reserves, so that if free radicals in body are formed excessively, it needs exogenous 
antioxidants, such as natural antioxidants from vegetables and fruits [9].

Natural ingredient which contain high antioxidants, especially flavonoids, for example nuts, vegetables, fruits, chocolate and tea [9]. Based on variety researches, one of vegetable that can suppress oxidative stress process is beans (Phaseolus vulgaris linn). Antioxidant activity in beans can protect body from lipid peroxidation and increase cellular antioxidant defenses. Research explains that beans compounds can increase SOD levels and decrease blood glucose levels in diabetic model mice [10]. Other ressearch also explains that giving bean juice to high glucose rats can reduce blood glucose levels in rats [11].

Benefits of beans both in vivo and in vitro have been widely publicized at this time, but no one has analyzed the effects of bean juice decreasing blood glucose levels in psychological stress models. So that, researchers are interested in examining the effects of bean juice in decreasing blood glucose levels in psychological stress models. The aim of this study was to examine the effectiveness of bean juice in reducing blood glucose activity in male white rats (wistar strains) exposed by psychological stress.

\section{METHOD}

This study was experimental laboratories research with Randomized Post Test Only Control Group Design, using 25 experimental white male rats strain Wistar (Rattus norvegicus), and divided into 5 groups. These groups are divided into a normal control group (K1); a stress control group (K2); a P1 treatment group, for blood glucose testing after 1 hour of giving green bean juice; a P2 treatment group, for blood glucose testing after 6 hours of giving green bean juice; and a P3 treatment group, for blood glucose testing after 24 hours of giving green bean juice. Previously, experimental rats were exposure by psychological stress. This condition can disturb rats' sleep pattern for 24 hours, so that these rats experienced oxidative stress, then blood glucose levels must be measured. The dose of bean juice is a single dose, amount 4.5 gram $/ 1 \mathrm{ml}$. This study was tested and passed the ethical test on April $4^{\text {th }}, 2018$ by Health Research Ethics Committee, Faculty of Public Health, Airlangga University.

\section{RESULTS AND DISCUSSION}

The results of this study are the average of blood glucose levels from experimental animals which are used to analyze the effects of bean juice in decreasing blood glucose levels due to psychological stress exposure, that causes oxidative stress. Research data will be processed using statistical data processing software SPSS for Windows v.21. Statistical test that was used in this study, was Manova test to determine the effects of independent variable with several dependent variables. The average of blood glucose levels in all groups from this study, can be shown by table 1 below:
Table 1. The Average of Blood Glucose Levels (mg/dL) For Control and Treatment Groups in White Male Rats (Wistar Strain)

\begin{tabular}{|l|c|c|}
\hline Group & n & Blood Glucose (mg/dL) \\
\cline { 3 - 3 } & & Mean $\mathbf{\text { SD }}$ \\
\hline K1 & 5 & $90,2 \pm 3,89872$ \\
K2 & 5 & $108,0 \pm 5,61249$ \\
P1 & 5 & $95,6 \pm 7,43640$ \\
P2 & 5 & $89,0 \pm 5,61249$ \\
P3 & 5 & $92,6 \pm 8,50294$ \\
\hline
\end{tabular}

Note:

K1: Control Group (Without Treatment)

K2: Exposured by Psychological Stress

P1: Psychological Stress + bean juice + measuring blood glucose levels after 1 hour

P2: Psychological Stress + bean juice + measuring blood glucose levels after 6 hours

P3: Psychological Stress + bean juice + measuring blood glucose levels after 24 hours

Based on the data above, the highest average of glucose levels was in the positive control group (K2) with a value of $108.0 \pm 5.61249 \mathrm{mg} / \mathrm{dL}$, where this group was given psychological stress treatment without giving bean juice. In normal group without treatment (K1), the average of blood glucose levels was $90.2 \pm 3.89872 \mathrm{mg} / \mathrm{dL}$. In treatment group (P1), the average of blood glucose levels decreased to $95.6 \pm 7.43640 \mathrm{mg} / \mathrm{dL}$, compared to positive control group (K2). Then, in treatment group (P2), the average of blood glucose levels decreased dramatically to $89.0 \pm$ $5.61249 \mathrm{mg} / \mathrm{dL}$, compared to $\mathrm{K} 2$ group and Treatment group (P1). Last, treatment group (P3), the average of blood glucose levels increased to $92.6 \pm 8.50294 \mathrm{mg} / \mathrm{dL}$, and this value was almost equal to the average of blood glucose levels in normal control group (K1).

Descriptive test results of blood glucose levels can be seen in the average distribution and standard deviation of blood glucose levels. Levene Test was used to examine homogeneity in this study, and the results showed that the data were homogeneous in all groups with a value of $p=$ 0.261 . Manova test was also used to analyze blood glucose levels in all groups and showed a value of $\mathrm{p}=0.001$ ( $\mathrm{p}$ $<0.05$ ). Based on these results, it can be concluded that there is a significant effect between green bean juice and decreased blood glucose levels. LSD test is also used to find out which groups have a significant difference. The difference can be said to be significant if the value of $p<$ 0.05 (attachment 4). LSD test results on blood glucose levels can be shown in table 2 below:

Table 2. P Value in LSD Test for Blood Glucose Levels

\begin{tabular}{|c|c|c|c|c|c|}
\hline Group & K1 & K2 & P1 & P2 & P3 \\
\hline K1 & - & $0,000^{*}$ & 0,198 & 0,770 & 0,561 \\
K2 & $0,000^{*}$ & - & $0.006^{*}$ & $0,000^{*}$ & $0,001^{*}$ \\
P1 & 0,198 & $0,006^{*}$ & - & 0,119 & 0,468 \\
P2 & 0,770 & $0,000^{*}$ & 0,119 & - & 0,386 \\
P3 & 0,561 & $0,001^{*}$ & 0,468 & 0,386 & - \\
\hline
\end{tabular}

Note:

K1: Control Group (Without Treatment) 
K2: Exposured by Psychological Stress

P1: Psychological Stress + bean juice + measuring blood glucose levels after 1 hour

P2: Psychological Stress + bean juice + measuring blood glucose levels after 6 hours

P3: Psychological Stress + bean juice + measuring blood glucose levels after 24 hours

LSD test results in table 2, show that there is a difference between Normal Control Group (K1) and Positive Control Group (K2) who received psychological stress treatment with a significant value of $\mathrm{p}=0,000$. Differences also occurred between Positive Control Group (K2) and Treatment Group $1(\mathrm{P} 1)$ with a significance value of $\mathrm{p}=$ 0.006 . Besides that, there is also difference between $\mathrm{K} 2$ and Treatment Group 2 (P2) with a significance value of $\mathrm{p}=$ 0,000 and also between K2 and Treatment Group 3 (P3) with a significance value of $p=0.001$. Other results show that there is no difference between Treatment Group 1 (P1) with $\mathrm{P} 2$ and $\mathrm{P} 3$. These results can be explained by the graph below:

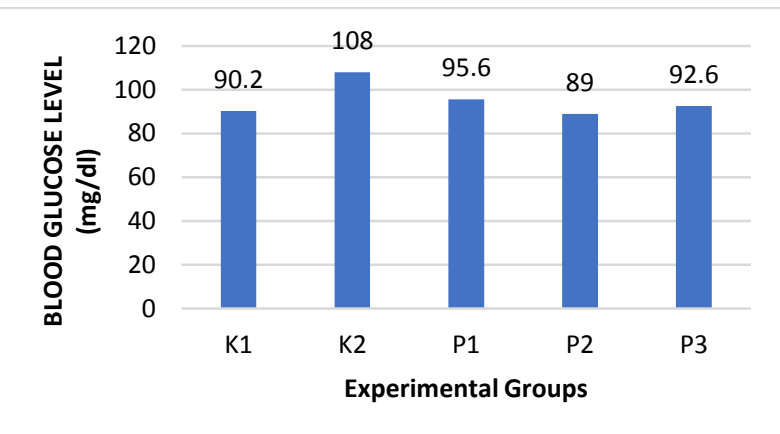

Figure 1. Mean Graph of Blood Glucose Levels (mg/dL) In All Experimental Groups

Figure 1 above, shows that there are differences between Normal Control Group (K1) and Positive Control Group (K2), between Positive Control Group (K2) and Treatment Group 1 (P1), Treatment Group 2 (P2), and Treatment Group 3 (P3). This figure also shows that there is no difference between Treatment Group 1 (P1), Treatment Group 2 (P2), and Treatment Group 3 (P3). Based on these data, by giving bean juice to male white rats (Wistar Strain) can reduce blood glucose levels in all treatment groups experiencing oxidative stress due to psychological stress exposure.

The aim of this study, was to analyze the role of antioxidants contained in bean juice (Phaseolus vulgaris Linn.) for reducing blood glucose levels. Based on the results of five treatment groups, it showed that the highest average of blood glucose levels was found in group K2. This group was exposure by psychological stress without giving of bean juice. On the other hand, the lowest blood glucose levels was found in group P2, which was given by psychological stress and then measured blood glucose levels at 6th hour after giving of bean juice dose $89 \mathrm{mg} / \mathrm{dL}$.
The results of this study also showed a significant difference in blood glucose levels between five treatment groups. Blood glucose levels in group $\mathrm{K} 1$, namely control group without psychological stress exposure and without giving of bean juice did not have a significant differences with treatment groups $\mathrm{P} 1, \mathrm{P} 2$, and $\mathrm{P} 3$, which these three groups were given bean juice and measured its blood glucose levels at $1^{\text {st }}$ hour, $6^{\text {th }}$ hour, and $24^{\text {th }}$ hour. This results show that, by giving bean juice dose 4.5 gram to experimental rats can reduce blood glucose levels that increase caused by psychological stress exposure, to a normal condition such as blood glucose levels in group K1 since $1^{\text {st }}$ hour of giving bean juice.

Increased acute and chronic blood glucose levels will cause oxidative stress [5]. Blood glucose is a molecule that is easily oxidized to produce reactive and radical molecules in blood. Increased blood glucose levels correlate with an increase of oxidative stress markers, namely Malondialdehyde (MDA) levels. Increased blood glucose levels cause cell damage due to buildup of intracellular ROS. This process occurs through the mechanism of nonenzymatic glycation in proteins that produce AGEs, sorbitol formation through polyol-sorbitol pathway (aldose reductase), and glucose autooxidation which will increase super oxide radicals, damage SOD enzymes, and activate PKC [12].

The study explains how oxidative stress mechanisms damage insulin stimulation from glucose transport activity. This study revealed that prolonged low-level oxidative stress impairs GLUT4 translocation that is stimulated by insulin, and it can interfere PI3K activation potentially, so that it can eventually cause an increase in blood glucose levels. Epinephrine excretion in response to stress stimuli can cause glycogenolysis in liver and muscles. Glycogenolysis increases glycolysis in muscles and liver which causes glucose to enter circulatory system, thereby increasing blood glucose levels [13]. This study is in line with the research which aims to determine the effect of acute psychological stress on glucose homeostasis in nondiabetic individuals. The results stated that patients with the highest stress levels had significantly higher blood glucose and insulin levels, and it was concluded that acute psychological stress was negatively correlated with insulin sensitivity [14].

Giving of bean juice (Phaseolus vulgaris linn) in this study, was proven to reduce blood glucose levels in experimental rats exposure by psychological stress, starting from the $1^{\text {st }}$ hour after giving bean juice, and still maintaining to decrease blood glucose levels at the $6^{\text {th }}$ hours and $24^{\text {th }}$ hours after giving of bean juice. This study is in line with the research that giving of bean extract can reduce blood glucose levels significantly, even more effective than giving of glibenclamide [15].

Increased glucose levels, as well as vasoconstriction and blood turbulence that occur continuously due to psychological stress conditions in experimental rats, can 
cause an increase in free radicals levels in the body. Arginine requirements will increase under stress, especially in high blood glucose levels condition. Other study explains that arginine supplementation can increase NO levels in DM rats, which increases NO levels can overcome vascular complications. Therefore, if arginine needs are fulfilled, it can increase NO formation and affect blood vessel endothelium quality, and reduce oxidative stress risk [16]. Flavonoid acts as antioxidants and chelating agents which significantly inhibit lipid peroxidation, chelate redox-active metals, and weaken other processes involving ROS [17]. Flavonoids as antioxidants can reduce oxidative stress and ROS, thus causing a protective effect in increasing insulin sensitivity. Flavonoid contents in beans can increase GLUT4 expression and PI3K/Akt activity, which can restore insulin sensitivity so that it decreases blood glucose levels [18].

\section{CONCLUSION}

Based on the results of this study, it can be concluded that upside down sleep pattern treatment can cause psychological stress and increase blood glucose levels in experimental rats. Bean juice as an exogenous antioxidant can reduce blood glucose levels that increase due to oxidative stress from the first hour to 24 hours after giving of bean juice. Blood glucose levels begin to decrease significantly since the first hour after giving of bean juice, and decrease maximally at the $6^{\text {th }}$ hour after giving of bean juice. Flavonoid contents in beans as an antioxidant, can reduce oxidative stress and ROS, so that it can be protective effect and increasing insulin sensitivity. Flavonoid, along with arginine will bind free radicals and reduce oxidative stress conditions, and finally blood glucose levels can decrease. Through the results of this study, can also be known the application of giving bean juice in daily life, shortly after psychological stress exposure. Bean juice can provide high antioxidant needs as a protection against oxidative stress (for example, at night shift workers, and conditions or jobs that require to stay up at night).

\section{REFERENCES}

[1] Hawari, Danang. (2016). Manajemen Stres, Cemas, dan Depresi. Jakarta. Fakultas Kedokteran Universitas Indonesia

[2] World Health Organization and Calouste Gulbenkian Foundation. (2014). Social Determinants of Mental Health. Geneva. http://apps.who.int/iris/bitstream/10665/112828/1/9 789241506809_eng.pdf sitasi 30 Desember 2017

[3] Riset Kesehatan Dasar (Riskesdas). (2013). Badan Penelitian dan Pengembangan Kesehatan. Kementerian Kesehatan RI Tahun 2013. Jakarta.

[4] Kestin AS, Ellis PA, Barnard MR. (1993). Effect of Strenyous Exercise on Platelet Activation State and Reactivity. Circulation. 1993; 88(1) P: 1502-1511.

[5] Vinna, J., Gimeno, A., Sastre, J., Desco, C., Asesnsi, M., Pallardo, F.V., Cuesta, A., Ferrero, J.A., Terada,
L.S., dan Repine, J.E. (2000). Mechanism of Free Radical Production in Exhaustive Exercise in Humans and Rats; Role of Xanthine Oxidase and Protection by Allopurionol. Informa Healthcare. 49 (6): 539-544.

[6] Yoshikawa T, Naito Y. (2002). What is Oxidative Stress?. Journal of the Japan Medical Association. Vol. 124, No.11, P. 1549-1553.

[7] Pham, Huy L, He H, Pham, Huy C. 2008). Free Radicals, Antioxidant and Disease in Health. International Journal of Biomedical Science. Vol. , No. 2. P. 89-96.

[8] Evans JL, Goldfine ID, Maddux BA, Grodsky GM. (2002). Oxidative Stress and Stress-Activated Signaling Pathways: A Unifying Hypothesis of Type 2 Diabetes. Endocrine Reviews, October 2002, 23(5) P. 599-622.

[9] Sayuti, Kesuma. (2015). Antioksidan, Alami dan Sintetik. Padang: Andalas University Press.

[10] Venkateswaran S, Pari L. (2002). Antioxidant Effect of Phaseolus vulgaris in Streptozotocin-induced Diabetic Rats. Asia Pacific J Clin Nutr (2002) 11 (3) P. 2016-209

[11] Onevita, Ludwina D. (2016). Pengaruh Pemberian Jus Buncis (Phaseolus vulgaris L.) terhadap Kadar Glukosa Darah Tikus Jantan Galur Wistar yang Terbebani Glukosa, skripsi. Fakultas Farmasi, Universitas Sanata Dharma Yogyakarta.

[12] Setiawan B, Suhartono. (2005). Stres Oksidatif dan Peran Antioksidan pada Diabetes Mellitus. Majalah Kedokteran Indonesia. Vol. 5 No.2, 2005.

[13] Bender, DA. (2009). Glukogenesis dan Kontrol Gula darah. Jakarta: Erlangga.

[14] Shiolah Eli, Witz Shula, Abramovitch Yehuda, Cohen Ohad, Buchs Andreas, Ramot Yoram, Weiss Mordechai, Unger Abraham, Rapoport Micha J. (2003). Effect of Acute Psychotic Stres in Nondiabetic Subjects on $\beta$-cell Function and Insulin Sensitivity. Diabetes Care 26: 1462-1467.

[15] Venkateswaran S, Pari L, Saravan GM. (2002). Effect of Phaseolus vulgaris on Circulatory Antioxidants and Lipids in Rats with Streptozotocin-induced Diabetes. Journal of Medical Food Vol.5 No. 2 (2002) P. 97-103.

[16] Sugiarto, Dinta. (2016). Efek Latihan Aerobik dan Suplementasi Arginin Terhadap Kadar Nitric Oxide pada Tikus Putih Model Diabetes Mellitus, tesis. Fakultas Kedokteran Universitas Airlangga Surabaya.

[17] Heim, Kelly E, Anthony R. Tagliaferro, Dennis J. Bobilya. (2002). Flavonoid Antioxidants: chemistry, metabolism and structure-activity relationships. Journal of Nutritional Biochemistry. 13 (2002) . P: 572-584.

[18] Hajiaghaalipour, Fatemeh, Khalilpourfarshbafi, Manizheh, Arya Aditya. 2015. Modulation of Glucose Transporter Protein by Dietary Flavonoids in Type 2 Diabetes Mellitus. International Journal of Biological Sciences. 2015; 11(5) P. 508-524. 